\title{
Performance Assessment of
}

\section{SOFC SYSTEMS INTEGRATED}

\section{WITH BIO-ETHANOL PRODUCTION}

\section{and PuRification Processes}

\section{Issara Choedkiatsakul ${ }^{1}$, Kanokporn Sintawarayan ${ }^{1}$, Tanya Prawpipat ${ }^{1}$, Apinan Soottitantawat ${ }^{1}$, Wisitsree Wiyaratn ${ }^{2}$, Worapon Kiatkittipong ${ }^{3}$, Amornchai Arpornwichanop ${ }^{1}$, Navadol Laosiripojana ${ }^{4}$, Sumittra Charojrochkul ${ }^{5}$ and Suttichai Assabumrungrat}

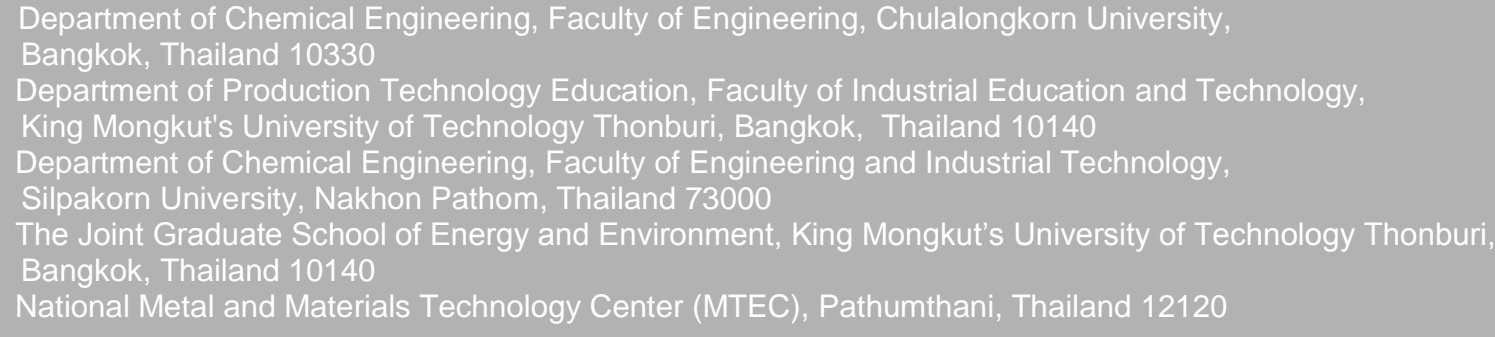

\section{ABSTRACT}

The overall electrical efficiencies of the integrated systems of solid oxide fuel cell (SOFC) with bio-ethanol production and purification processes at different levels of heat integration were investigated. The simulation studies were based on the condition with zero net energy (no external heat required). It was found that the most suitable operating condition of SOFC is at voltage between 0.7 and $0.85 \mathrm{~V}$ and temperature between 973 and $1173 \mathrm{~K}$. Regarding the effect of percent ethanol recovery, the optimum percent ethanol recovery is observed at 95\%. The SOFC integrated with bio-ethanol production and purification processes with reforming of biogas for producing extra hydrogen is found to be the most efficient system, offering the overall electrical efficiency of $36.17 \%$. However, additional equipments such as biogas reformer and heat exchangers are required, resulting in increased investment cost.

\section{KEYWORDS}

solid oxide fuel cell, bioethanol, electrical efficiency, heat integration 


\section{Introduction}

Nowadays, energy crisis is the crucial issue due to the increasing energy demand with the limiting of fossil fuels sources. Therefore, renewable energy has become an interesting topic for many researchers. Bio-ethanol is one of the attractive resources of renewable energy. It has extra advantages in term of production because it can be easily produced from biomass such as cassava, molasses and bagasse. Bio-ethanol can be further reformed to hydrogen which is a major fuel for solid oxide fuel cell (SOFC) to generate useful electricity and heat.

In this study, performance assessment of SOFC systems integrated with bio-ethanol production and purification processes was investigated. Bio-ethanol produced from cassava was considered. The energy consumption required at different unit operations were reported elsewhere [1], [2]. Biogas, a byproduct from bio-ethanol production, was also considered in this work as an additional fuel for generating heat or extra hydrogen for the system [1], [3]. The purification process of bio-ethanol to a higher ethanol concentration before being reformed to hydrogen for use in SOFC was studied by simulation using Aspen Plus ${ }^{\text {TM }}$ program [4], [5]. The optimal conditions for the purification process are the conditions that provide the minimum required energy. For the SOFC system, Microsoft visual basic program was used to simulate and find the appropriate operating conditions [6], [7]. The work compares performance of various SOFC systems at different levels of heat integration in order to find a suitable system.

\section{Modeling System}

\subsection{Energy consumption in ethanol production process}

Bio-ethanol production process composes of milling, mixing, liquefaction, saccharification, fermentation, distillation, post-treatment and rectification [1]. The energy consumption per ton of ethanol produced for each unit of the process is shown in Table 1.

\begin{tabular}{|l|c|c|}
\hline \multicolumn{1}{|c|}{ Stage } & Electricity $(\mathbf{k W h})$ & Heat $\mathbf{( k W h )}$ \\
\hline Milling and mixing & 30.24 & - \\
\hline Liquefaction and Saccharification & 12.96 & 875.91 \\
\hline Fermentation & 41.9 & - \\
\hline Distillation & 24.24 & $2,802.92$ \\
\hline Post-treatment & 70.47 & 963.5 \\
\hline supplementary equipment & 19.8 & 87.59 \\
\hline Biogas cogeneration (self supply) & -204.73 & -822.49 \\
\hline Net Energy use $(\mathrm{kWh})$ & -5.12 & $3,907.43$ \\
\hline Overall energy use $(\mathrm{kWh})$ & $3,902.31$ & - \\
\hline
\end{tabular}

Table 1

Energy consumption in ethanol production process (per ton of $95.6 \% \mathrm{w} / \mathrm{w}$ ethanol) [2]

\subsection{Distillation modeling}

The schematic diagram of the purification process is shown in Fig.1. Low ethanol concentration was purified to a desired level of ethanol concentration by the distillation column. The Radfrac rigorous equilibrium stage distillation module in Aspen ${ }^{\mathrm{TM}}$ plus program was used to simulate the process. The distillate stream from the distillation column was heated to the reformer temperature $(1023 \mathrm{~K})$ by Heater 1 . The bottom stream containing mostly water was partially removed and heated by Heater 2 in order to mix with the distillate stream to get the $25 \mathrm{~mol} \%$ ethanol concentration before being fed to the reformer. 
Figure 1

Schematic diagram of the purification process

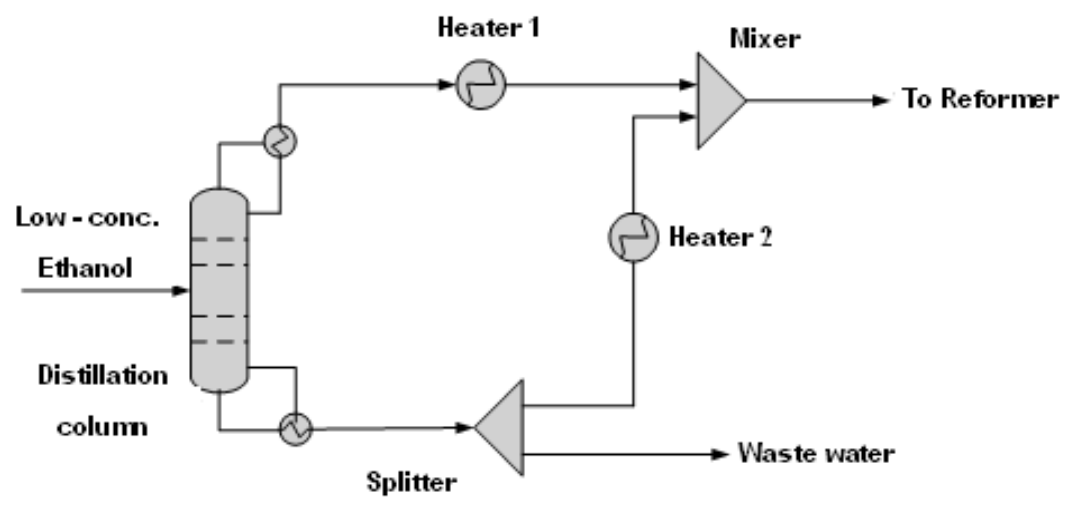

\subsection{SOFC modeling}

Fig. 2 shows the schematic diagram of SOFC system. The $25 \mathrm{~mol} \%$ ethanol concentration was fed to the external reformer. The calculation was based on phase and chemical equilibrium. Excess air (500\%) was preheated and fed to the cathode chamber of the SOFC stack. Generally, biogas which is a byproduct from the ethanol production process could be collected in order to produce steam and electricity or fed to the reformer to produce additional hydrogen gas for feeding to SOFC. Table 2 shows the amount and compositions of biogas.

Figure 2

Schematic diagram of SOFC system

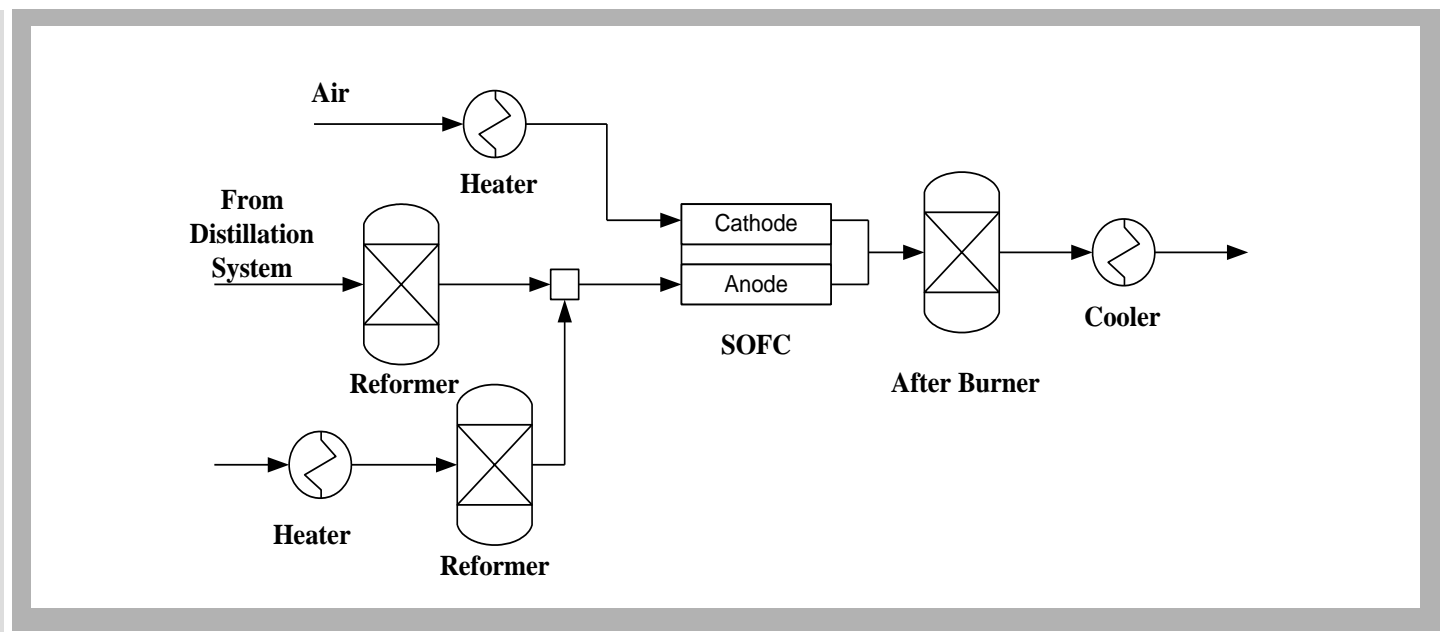

Table 2

The amount and composition of

biogas per ton of ethanol produced

\begin{tabular}{|c|c|}
\hline Component & Amount (mol) \\
\hline $\mathrm{CH}_{4}$ & 7,466 \\
\hline $\mathrm{CO}_{2}$ & 1,014 \\
\hline $\mathrm{O}_{2}$ & 197 \\
\hline $\mathrm{N}_{2}$ & 740 \\
\hline
\end{tabular}


In order to simplify the calculations, the reformer was assumed to operate isothermally and the outlet gas reached its equilibrium composition. The main reaction of biogas reforming is the steam reforming reaction (Eq. (1)) and the other reaction is water gas shift reaction (Eq. (2)) [5-6].

$$
\begin{aligned}
& \mathrm{CH}_{4}+\mathrm{H}_{2} \mathrm{O} \longrightarrow 3 \mathrm{H}_{2}+\mathrm{CO} \\
& \mathrm{CO}+\mathrm{H}_{2} \mathrm{O} \longrightarrow \mathrm{CO}_{2}+\mathrm{H}_{2}
\end{aligned}
$$

In SOFC stack, the electrochemical reaction takes place. Oxygen from air is reduced to oxygenions (Eq. (3)) at the cathode side and passes through the electrolyte to react with the hydrogen gas at the anode side (Eq. (4)). It was reported that $\mathrm{H}_{2}$ electrooxidation is much faster than $\mathrm{CO}$ electro-oxidation and the rate of water gas shift reaction is very fast at high temperatures. Therefore, it is assumed that only hydrogen ions react with oxygen ions.

$$
\begin{aligned}
& 1 / 2 \mathrm{O}_{2}+2 \mathrm{e}^{-} \longrightarrow \mathrm{O}^{2-} \\
& \mathrm{H}_{2}+\mathrm{O}^{2-} \longrightarrow \mathrm{H}_{2} \mathrm{O}+2 \mathrm{e}^{-}
\end{aligned}
$$

The open circuit voltage $(E)$ can be calculated by using the Nernst equation below

$$
E=E_{0}+\frac{R T}{2 F} \ln \left(\frac{P_{\mathrm{H}_{2}} \mathrm{P}_{\mathrm{O}_{2}}^{1 / 2}}{\mathrm{P}_{\mathrm{H}_{2} \mathrm{O}}}\right)
$$

where $E_{0}$ is the reversible potential $(\mathrm{V}), R$ is the gas constant $(8.3145 \mathrm{~J} / \mathrm{mol} . \mathrm{K}), T$ is the SOFC temperature $(\mathrm{K}), F$ is the Faraday constant $(9.6495104 \mathrm{C} / \mathrm{mol})$ and $P_{i}$ is partial pressure of species $i(\mathrm{~Pa})$.

The actual cell potential $(V)$ is always less than the open circuit voltage $(E)$ owing to the existence of the overpotentials as shown by Eq. (6).

$$
V=E-\eta_{\text {act }}-\eta_{\text {ohmic }}-\eta_{\text {conc }}
$$

The overpotentials are divided into three types: ohmic overpotential $\left(\eta_{\mathrm{ohmic}}\right)$, activation overpotential $\left(\eta_{\text {act }}\right)$ and concentration overpotential $\left(\eta_{\text {conc }}\right)$ which can be explained as below [6]:

\subsubsection{Ohmic overpotential}

The ohmic overpotential is the resistance of the electron to flow through the electrodes, interconnections and electrolyte. This overpotential is the major loss of the SOFC stack which can be calculated from Eq. (7).

$$
\eta_{\text {ohmic }}=2.99 \times 10^{-11} \mathrm{iL} \exp \left(\frac{10300}{\mathrm{~T}}\right)
$$

where $i$ is the current density $\left(\mathrm{A} / \mathrm{cm}^{2}\right)$ and $L$ is the thickness of the electrolyte $(\mu \mathrm{m})$.

\subsubsection{Activation overpotential}

The activation overpotential occurs from the electrochemical reaction at the electrodes. Normally, the activation overpotential dominates at low current density but at high temperature, the reaction rate is very fast then this value is small. This overpotential can be expressed by the Butler-Volmer equation.

$$
i=i_{0}\left[\exp \left(\frac{\alpha z F \eta_{\text {act }}}{R T}\right)-\exp \left(-\frac{(1-\alpha) z F \eta_{\text {act }}}{R T}\right)\right]
$$


where $i_{0}$ is the exchange current density $\left(\mathrm{A} / \mathrm{cm}^{2}\right), \alpha$ is the symmetrical factor and $z$ is the number of electrons that involve in the reaction. In case of SOFC, the value of $\alpha$ and $z$ are 0.5 and 2 respectively. Consequently, the activation overpotential at anode and cathode side can be written as:

$$
\eta_{\text {act, }, j}=\frac{R T}{F} \sinh ^{-1}\left(\frac{\mathrm{i}}{2 \mathrm{i}_{0}}\right) \quad \mathrm{j}=\mathrm{a}, \mathrm{c}
$$

The exchange current density $\left(i_{0}\right)$ for the cathode and anode sides can be calculated from the following equations:

$$
\begin{aligned}
& \mathrm{i}_{0, \mathrm{a}}=\gamma_{\mathrm{a}}\left(\frac{\mathrm{P}_{\mathrm{H}_{2}}}{\mathrm{P}_{\text {ref }}}\right)\left(\frac{\mathrm{P}_{\mathrm{H}_{2} \mathrm{O}}}{\mathrm{P}_{\text {ref }}}\right) \exp \left(-\frac{\mathrm{E}_{\mathrm{act,a}}}{\mathrm{RT}}\right) \\
& \mathrm{i}_{0, \mathrm{c}}=\gamma_{\mathrm{c}}\left(\frac{\mathrm{P}_{\mathrm{O}_{2}}}{\mathrm{P}_{\text {ref }}}\right)^{0.25} \exp \left(-\frac{\mathrm{E}_{\mathrm{act}, \mathrm{c}}}{\mathrm{RT}}\right)
\end{aligned}
$$

where $\gamma_{i}$ is the pre-exponential factor for electrode exchange current density $\left(\mathrm{A} / \mathrm{cm}^{2}\right), E_{\text {act,i } i}$ is the activation energy of electrode $(\mathrm{J} / \mathrm{mol})$, subscripts a and $\mathrm{C}$ represent anode and cathode, respectively.

\subsubsection{Concentration overpotential}

The concentration overpotential is the loss due to the difference in concentration of gas between the bulk and the reaction site. It can be estimated by Eqs. (12) and (13)

$$
\begin{aligned}
& \eta_{\text {conc }, \mathrm{a}}=\frac{R T}{2 \mathrm{~F}} \ln \left[\frac{\left(1+(\mathrm{RT} / 2 \mathrm{~F})\left(\mathrm{I}_{\mathrm{a}} / \mathrm{D}_{\mathrm{a}(\text { eff })} \mathrm{p}_{\mathrm{H}_{2} \mathrm{O}}^{\prime}\right) \mathrm{i}\right)}{\left(1-(\mathrm{RT} / 2 \mathrm{~F})\left(\mathrm{I}_{\mathrm{a}} / \mathrm{D}_{\mathrm{a}(\text { eff }} \mathrm{p}_{\mathrm{H}_{2}}^{\prime}\right) \mathrm{i}\right)}\right] \\
& \eta_{\text {conc, } \mathrm{c}}=\frac{\mathrm{RT}}{4 \mathrm{~F}} \ln \left[\frac{\mathrm{p}_{\mathrm{O}_{2}}^{\prime}}{\left(\mathrm{p}_{\mathrm{c}}-\delta_{\mathrm{O}_{2}}\right)-\left(\left(\mathrm{p}_{\mathrm{c}}-\delta_{\mathrm{O}_{2}}\right)-\mathrm{p}_{\mathrm{O}_{2}}^{\prime}\right) \exp \left[(\mathrm{RT} / 4 \mathrm{~F})\left(\delta_{\mathrm{O}_{2}} \mathrm{I}_{\mathrm{c}} / \mathrm{D}_{\mathrm{c}(\text { eff })} \mathrm{p}_{\mathrm{c}}\right) \mathrm{i}\right]}\right]
\end{aligned}
$$

where $I_{a}, I_{c}$ are the thicknesses of anode and cathode $(\mu \mathrm{m}), p_{i}^{\prime}$ is the inlet pressure of species $i(\mathrm{~Pa}), D_{a(e f f)}$ and $D_{c(\text { eff })}$ are the effective diffusion coefficient of the anode and cathode $\left(\mathrm{cm}^{2} / \mathrm{s}\right)$ and $p_{a}, p_{c}$ are the operating pressure of SOFC at the anode and cathode sides $(\mathrm{Pa}) . \delta_{\mathrm{O} 2}, D_{a(\text { eff })}$ and $D_{c(\text { eff })}$ can be expressed by:

$$
\begin{gathered}
\delta_{\mathrm{O}_{2}}=\frac{\mathrm{D}_{\mathrm{O}_{2}, \mathrm{k}(\text { eff })}}{\mathrm{D}_{\mathrm{O}_{2}, \mathrm{k}(\text { eff })}+\mathrm{D}_{\mathrm{O}_{2}-\mathrm{N}_{2} \text { (eff) }}} \\
\mathrm{D}_{\mathrm{a}(\text { eff })}=\left(\frac{\mathrm{p}_{\mathrm{H}_{2} \mathrm{O}}}{\mathrm{P}_{\mathrm{a}}}\right) \mathrm{D}_{\mathrm{H}_{2} \text { (eff) }}+\left(\frac{\mathrm{p}_{\mathrm{H}_{2}}}{\mathrm{P}_{\mathrm{a}}}\right) \mathrm{D}_{\mathrm{H}_{2} \mathrm{O} \text { (eff) }} \\
\mathrm{D}_{\mathrm{c}(\text { eff })}=\frac{\xi}{\mathrm{n}}\left(\frac{1}{\mathrm{D}_{\mathrm{O}_{2}, \mathrm{k}}}+\frac{1}{\mathrm{D}_{\mathrm{O}_{2}-\mathrm{N}_{2}}}\right) \\
\frac{1}{D_{\left.\mathrm{H}_{2} \text { (eff }\right)}}=\frac{\xi}{\mathrm{n}}\left(\frac{1}{\mathrm{D}_{\mathrm{H}_{2}, \mathrm{k}}}+\frac{1}{\mathrm{D}_{\mathrm{H}_{2}-\mathrm{H}_{2} \mathrm{O}}}\right)
\end{gathered}
$$




$$
\frac{1}{\mathrm{D}_{\mathrm{H}_{2} \mathrm{O}(\text { eff })}}=\frac{\xi}{\mathrm{n}}\left(\frac{1}{\mathrm{D}_{\mathrm{H}_{2} \mathrm{O}, \mathrm{k}}}+\frac{1}{\mathrm{D}_{\mathrm{H}_{2}-\mathrm{H}_{2} \mathrm{O}}}\right)
$$

where $D_{i, k(e f f)}$ is the effective Knudsen diffusivity of gas $i\left(\mathrm{~cm}^{2} / \mathrm{s}\right), D_{A-B(\text { eff })}$ is the effective ordinary diffusivity of gas $A$ versus gas $B\left(\mathrm{~cm}^{2} / \mathrm{s}\right), D_{i, k}$ is the Knudsen diffusivity of gas $i\left(\mathrm{~cm}^{2} / \mathrm{s}\right), D_{A-B}$ is the ordinary diffusivity of gas $A$ versus gas $B\left(\mathrm{~cm}^{2}\right.$ $/ \mathrm{s})$ and $\xi$ is the electrode tortuosity $(\mu \mathrm{m})$.

Eq. (19) shows the relationship between effective parameter $\left(D_{(\text {eff })}\right)$ and nominal parameter $(D)$ :

$$
D_{(\text {eff })}=\frac{n}{\xi} D
$$

The correlation below is used to calculate the Knudsen diffusivity:

$$
D_{A, k}=9700 \sqrt{\frac{T}{M_{A}}}
$$

where $M_{A}$ is the molecular weight of gas $\mathrm{A}(\mathrm{g})$.

The Chapman-Enskog equation is used for calculating the ordinary diffusivity:

$$
D_{A-B}=1.8583 \times 10^{-3}\left(\frac{T^{3 / 2}\left(\left(1 / M_{A}\right)+\left(1 / M_{B}\right)\right)^{1 / 2}}{P \sigma_{A B}^{2} \Omega_{D}}\right)
$$

where $\sigma_{A B}$ is collision diameter $\left(\mathrm{A}^{\circ}\right)$ which is equal to $\left(\sigma_{A}+\sigma_{B}\right) / 2$ and $\Omega_{D}$ is the collision integral which can be calculated from the following equation.

$$
\Omega_{D}=\frac{A}{T_{k}^{B}}+\frac{C}{\exp \left(D T_{k}\right)}+\frac{E}{\exp \left(F T_{k}\right)}+\frac{G}{\exp \left(H T_{k}\right)}
$$

\begin{tabular}{|c|c|c|c|}
\hline Parameters & Value & Parameters & Value \\
\hline$L \quad(\mu \mathrm{m})$ & 50 & $\sigma_{H_{2}}(\AA)$ & 2.827 \\
\hline$E_{a c t, a}(\mathrm{~J} / \mathrm{mol})$ & $1.0 \times 10^{5}$ & $\sigma_{\mathrm{H}_{2} \mathrm{O}}(\AA)$ & 2.641 \\
\hline$E_{a c t, c}(\mathrm{~J} / \mathrm{mol})$ & $1.2 \times 10^{5}$ & $\sigma_{N_{2}}(\AA)$ & 3.798 \\
\hline$\gamma_{a}\left(\mathrm{~A} / \mathrm{m}^{2}\right)$ & $1.344 \times 10^{10}$ & $\sigma_{O_{2}}(\AA)$ & 3.467 \\
\hline$\gamma_{c} \quad\left(\mathrm{~A} / \mathrm{m}^{2}\right)$ & $2.051 \times 10^{9}$ & $\varepsilon_{H_{2}}$ & 59.7 \\
\hline$l_{a} \quad(\mu \mathrm{m})$ & 750 & $\varepsilon_{\mathrm{H}_{2} \mathrm{O}}$ & 809.1 \\
\hline$I_{c} \quad(\mu \mathrm{m})$ & 50 & $\varepsilon_{N_{2}}$ & 71.4 \\
\hline$\xi \quad(\mu \mathrm{m})$ & 5.4 & $\varepsilon_{O_{2}}$ & 106.7 \\
\hline$n$ & 0.48 & & \\
\hline
\end{tabular}

where $T_{k}$ is equal to $T / \varepsilon_{A B}, \quad \varepsilon_{A B}$ is the Lennard-Jones energy interaction parameter scaled with respect to the Boltzman constant and $A, C, E$ and $G$ are constants for each gas.

The overall parameters used in this model are summarized in Table 3.

Table 3

Summary of model parameters [6] 
The effluents from the cathode and anode sides were fed to the afterburner. The complete combustion was assumed to occur in the afterburner; therefore the exit gas from the afterburner consists of nitrogen, oxygen, water and carbon dioxide. The exhaust gas temperature was reduced to $403 \mathrm{~K}$ and it was assumed to operate without heat loss.

The overall electrical efficiency of the system can be computed by Eq. (23):

$$
\text { \%Overall Eff. }=\frac{\mathrm{W}_{\text {enet }}}{\mathrm{n}_{\mathrm{EtOH}} \cdot \mathrm{LHV}_{\text {EtOH }}+\mathrm{n}_{\text {Biogas }} \cdot \mathrm{LHV}_{\text {Biogas }}+\text { Required External Heat }}
$$

where $W_{e, \text { net }}$ is the net electrical power (MW), $n_{i}$ is the flow rate of component $i$ $(\mathrm{mol} / \mathrm{s})$ and $L H V_{i}$ is the lower heating value of component $i(\mathrm{~kJ} / \mathrm{kg})$.

In this work we divided the case studies into four systems in order to compare performance of the system with different levels of heat integration. The details of each system are shown below:

System 1: SOFC system fed by high concentration ethanol. High concentration ethanol (95.6 wt.\%) was used as a feed for this system. It was diluted with water to $25 \mathrm{~mol} \%$ ethanol solution and fed to the reformer, generating hydrogen for use in the SOFC system.

System 2: SOFC system fed by bio-ethanol pre-purified to $25 \mathrm{~mol} \%$ of ethanol concentration.

System 3: Integrated system of SOFC and bio-ethanol purification process. In this case, bio-ethanol was purified to an optimal concentration of ethanol and diluted to $25 \mathrm{~mol} \%$ ethanol before being fed to the reformer and later to the SOFC system. Heat integration between the SOFC and the bio-ethanol purification process was allowed. For example, heat from the SOFC system was recovered to use for preheating the bio-ethanol feed and for the supplying energy to the reboiler of the distillation column.

System 4: Integrated system of SOFC and bio-ethanol production and purification processes. Heat integration between the SOFC and bio-ethanol production and purification processes was allowed. As biogas is a byproduct in the bio-ethanol production process, two systems with different ways of biogas utilization were considered.

4.1 Biogas for cogeneration: biogas generated during the bio-ethanol production was burnt to generate heat for use in the integrated system.

4.2 Biogas for hydrogen production for SOFC: the system is similar to 4-1 but biogas was fed to the reforming process to produce extra hydrogen gas as a fuel for SOFC.

\section{Results and Discussions}

\subsection{Effect of ethanol concentration on energy requirement in distillation system}

The minimum energy consumption in the distillation system can be obtained by varying the parameters, i.e. purity of ethanol in the distillate, percent ethanol recovery, the number of the column stages and the feed stage. The appropriate operating conditions from the simulation are listed in Table 4 for different values of ethanol recovery. 


\begin{tabular}{|c|c|c|c|c|c|}
\hline \multirow{2}{*}{ Parameters } & \multicolumn{5}{|c|}{ Ethanol Recovery } \\
\cline { 2 - 6 } & $80 \%$ & $85 \%$ & $90 \%$ & $95 \%$ & $99 \%$ \\
\hline Ethanol purity & 40 & 35 & 35 & 35 & 35 \\
\hline No. of stages & 5 & 5 & 6 & 6 & 6 \\
\hline Feed stage & 2 & 2 & 3 & 2 & 2 \\
\hline $\begin{array}{c}\text { Net Heat Duty } \\
\text { (MJ/ton EtOH) }\end{array}$ & 8,973 & 9,065 & 9,552 & 9,790 & 11,048 \\
\hline
\end{tabular}

Table 4

The appropriate operating conditions for distillation

\subsection{Effects of SOFC operating voltage and fuel utilization on the SOFC performance}

The system becomes more efficient when operated at the conditions at which the net useful heat $\left(Q_{n e t}\right)$ is equal to zero because it achieves the maximum electricity for the overall system without requiring the external heat source. The value of $Q_{\text {net }}$ is equal to zero means that the exothermic energy is exactly capable to supply to the required energy demanding units. However, the value of $Q_{\text {net }}$ can also be positive or negative. A positive value of $Q_{n e t}$ means that there is some heat left from the overall process and the negative value indicates that the external heat source is required to supply for the energy consuming units.

At a higher fuel utilization $\left(U_{f}\right)$, the higher net useful electrical power $\left(W_{e, n e t}\right)$ was obtained when operated at higher voltages because the lower heat loss was emitted from the SOFC stack. As a result of the higher $W_{\text {e,net }}$, the lower net useful heat $\left(Q_{\text {net }}\right)$ was obtained. The appropriate voltages at which $Q_{\text {net }}$ equals to zero for $U_{f}=70,80$ and $90 \%$ were $0.75,0.65$ and $0.575 \mathrm{~V}$, respectively. The corresponding values of power density $(P)$ were equaled to $3,000,3,700$ and $4,200 \mathrm{~W} / \mathrm{m}^{2}$.

\subsection{Appropriate operating conditions for SOFC system}

From Fig 3a), $W_{\text {enet }}$ and overall efficiency increased with the increase of ethanol recovery up to $95 \%$. Although at the higher ethanol recovery, the required energy for distillation system increased, the amount of ethanol provided to SOFC system increased. Consequently, the overall efficiency was higher when increasing the percent ethanol recovery to $95 \%$. However, when percent ethanol recovery was between $95 \%$ and $99 \%$, the performance started to decrease gradually and dramatically reduced at the percent ethanol recovery greater than $99 \%$ because the significantly higher energy required in the distillation system caused the SOFC system to operate at a lower fuel utilization in order to leave more un-reacted fuel to burn and compensate the higher heat demanded. This led to the reduction of the overall efficiency. The optimal percent ethanol recovery which obtained the maximum $W_{\mathrm{e} \text {,net }}$ and overall efficiency was observed at $95 \%$ which was used to determine the appropriate operating voltage and temperature of SOFC as in Figs.3b) and 3c), respectively.

Fig.3b) indicates that the SOFC stack area increased with increasing the operating voltage while $Q_{\text {stack }}$ decreased. The appropriate operating voltage should not be too low because it may cause the excessive heat generated in the stack which can directly damage the thermophysical property of the cell components. The most suitable operating voltage was in the range from 0.7 to $0.85 \mathrm{~V}$. As the same reason as operating voltage, the operating temperature should not be too high. Therefore the suitable operating temperature for SOFC was in the range from 973 to $1173 \mathrm{~K}$ as shown in Fig. 3c). 
a)
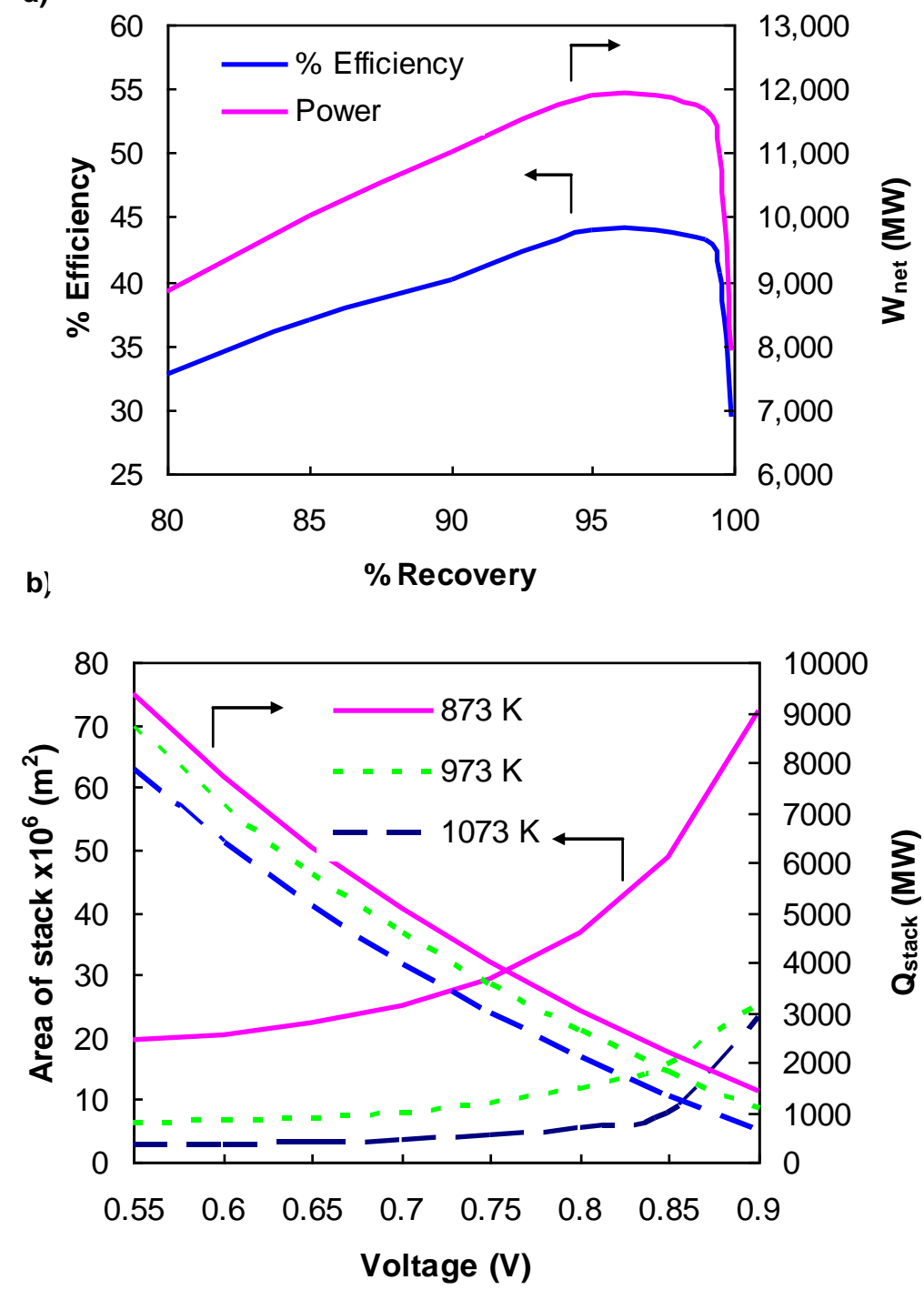

$\sum_{\substack{0 \\ 0 \\ \frac{\pi}{0}}}^{\substack{0 \\ 0}}$

c)

Figure 3

The effect of a) \% ethanol recovery on the $W_{\text {enet }}$ and the overall efficiency b) and c) operating voltage and operating temperature on SOFC stack area and $Q_{\text {stack }}$

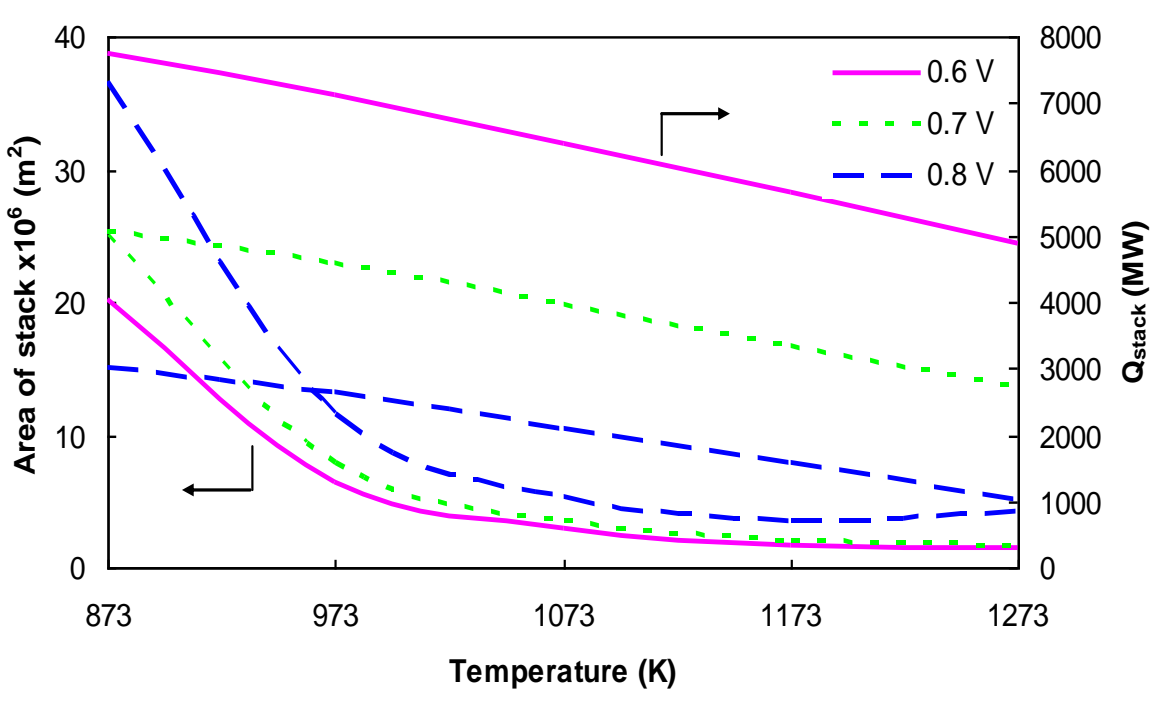




\subsection{Efficiency comparison among different systems.}

\subsubsection{Efficiency comparison in case of equal SOFC power density}

In this section, the performance of different SOFC systems is compared to determine a suitable system for operation. Table 5 shows the net electrical power, the required external heat source and the overall electrical efficiency of each system. It can be seen that for the systems No.1, 2 and 3, the external heat source was required since the ethanol production process and/or the distillation system were not integrated with the SOFC system and therefore the heat released from the SOFC system can not be provided to the other systems. Consequently, the values of overall electrical efficiency are low. In contrast, the system no. 4 was the combination of all three systems; therefore the external heat source was not required. The simulation results indicated that the system 4-2 offered the highest overall efficiency with no external heat required.

\begin{tabular}{|c|c|c|c|}
\hline System & $\boldsymbol{W}_{\mathrm{e}, \mathrm{net}}(\mathbf{M W})$ & $\begin{array}{c}\text { External Heat } \\
\text { Required (MW) }\end{array}$ & $\begin{array}{c}\text { \%Overall } \\
\text { Electrical } \\
\text { Efficiency }\end{array}$ \\
\hline 1 & 10,643 & 14,067 & 22.64 \\
\hline 2 & 10,135 & 9,871 & 23.67 \\
\hline 3 & 10,135 & 3,976 & 27.45 \\
\hline 4.1 & 10,135 & 0 & 30.76 \\
\hline 4.2 & 11,908 & 0 & 36.14 \\
\hline
\end{tabular}

Table 5

Efficiency comparison in case of equal SOFC power density (Ethanol Recovery = $95 \%$, Operating voltage $=0.7 \mathrm{~V}$ Temperature $=1073$ $\mathrm{K}, \mathrm{P}=3,619 \mathrm{~W} / \mathrm{m}^{2}$ )

\subsubsection{Efficiency comparison in case of equal SOFC stack area}

The simulation results are shown in Table 6. It was found that the most attractive system is system no. 4. As the systems $4-1$ and 4-2 had the competitive efficiency; hence, further study was necessary.

\begin{tabular}{|c|c|c|c|}
\hline System & $\boldsymbol{W}_{\mathrm{e}, \text { net }}(\mathbf{M W})$ & $\begin{array}{c}\text { External Heat } \\
(\mathbf{M W})\end{array}$ & \%Efficiency \\
\hline 1 & 11,354 & 14,067 & 24.15 \\
\hline 2 & 11,224 & 9,871 & 26.21 \\
\hline 3 & 11,224 & 3,976 & 30.40 \\
\hline 4.1 & 11,224 & 0 & 34.06 \\
\hline 4.2 & 11,046 & 0 & 33.52 \\
\hline
\end{tabular}

Table 6

Efficiency comparison in case of equal SOFC stack area (Ethanol Recovery $=95 \%$, Operating voltage $=$ $0.7 \mathrm{~V}$, Temperature $=1073 \mathrm{~K}, P=3,619$ $\mathrm{W} / \mathrm{m}^{2}$ )

\subsection{Effects of SOFC operating conditions on SOFC performance: comparison between biogas cogeneration and biogas reforming for hydrogen production}

\subsubsection{Comparison on net useful heat and overall electrical efficiency}

Table 7 shows the results for both systems. It can be seen that both systems offered comparable overall electrical efficiency and $W_{\mathrm{e}, \text { net. }}$ In fact, system 4-2 should give the 
higher efficiency and electricity than system 4-1 because the extra amount of hydrogen fuel was fed to SOFC system. However, the operation required the extra heat to increase biogas temperature and for biogas reforming; therefore SOFC has to operate at a lower value of fuel utilization in order to leave enough fuel for combustion to compensate the additional heat required. Consequently, the overall efficiency decreased.

Table 7

Net useful heat and overall efficiency of two systems $(95 \%$ ethanol recovery)

\begin{tabular}{|c|c|c|}
\hline System & $\boldsymbol{W}_{\mathrm{e}, \text { net }}(\mathbf{M W})$ & \%Efficiency \\
\hline $4-1$ & 11,885 & 36.07 \\
\hline $4-2$ & 11,917 & 36.17 \\
\hline
\end{tabular}

\subsubsection{Comparison on power density and SOFC stack area}

The effects of operating voltage and temperature on the power density and SOFC stack area are illustrated on Figs.4a-4b

a)

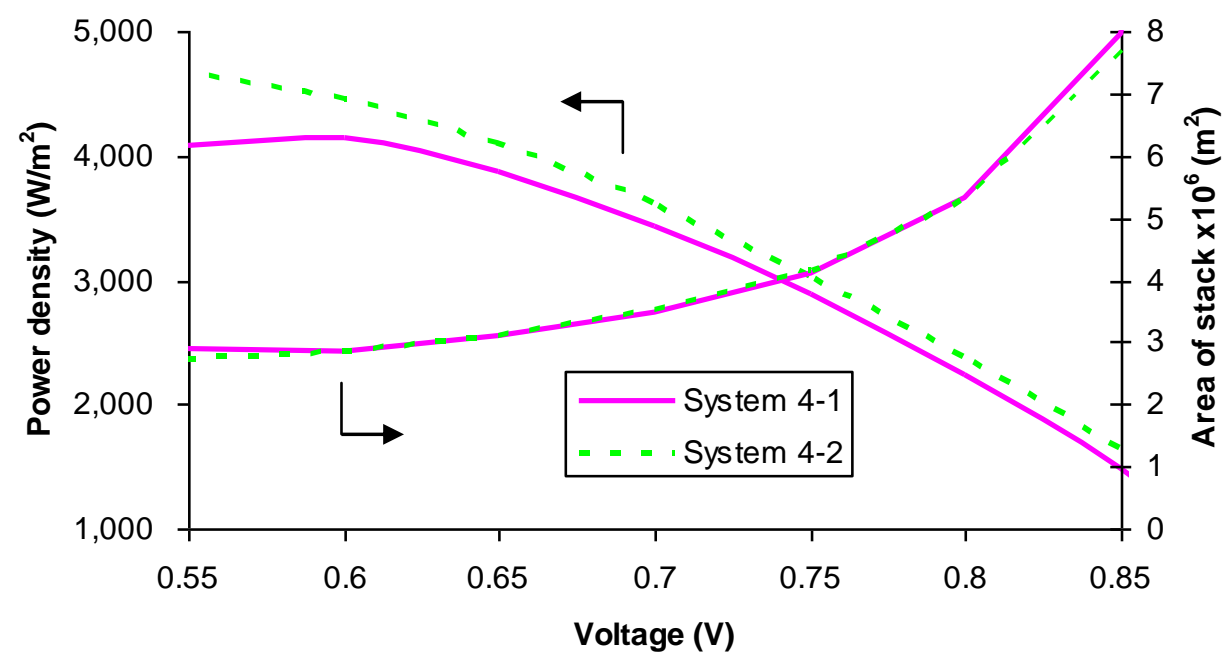

b)

Figure 4

(a) Effects of operating voltage on the power density and SOFC stack area $(95 \%$ ethanol recovery, $T_{\text {SOFC }}=$ $1073 \mathrm{~K}$ )

(b) Effects of operating

temperature on the power density and SOFC stack area (95\% ethanol recovery, $V=0.7 \mathrm{~V}$ )

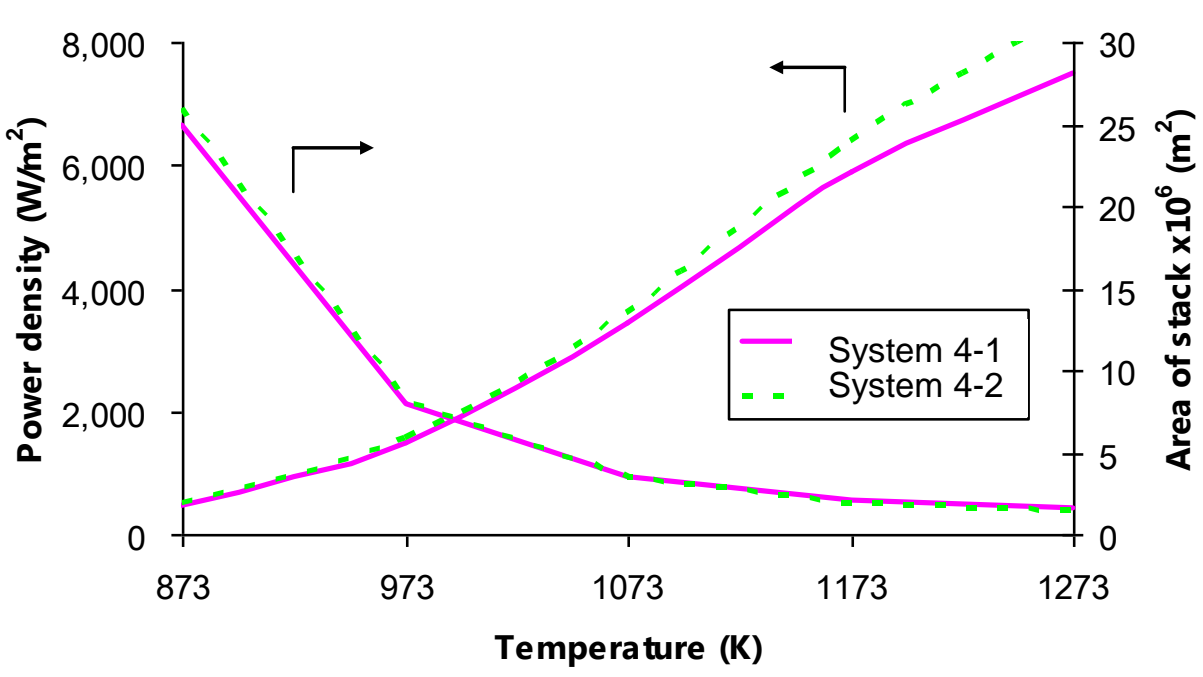


From Fig.4a) when the operating voltage increased, the power density decreased and thus the required stack area increased. For the effect of operating temperature as shown in Fig.4b), increasing operating temperature can improve power density and thus reduce the stack area. In addition, it can be seen that the power density in the system No.4-2 was about 5\% greater than the other system while the SOFC stack area for both systems was almost the same. It should be noted that even though the system No.4-2 had the advantages of higher net electrical power and power density but it requires more unit operations such as biogas reformer and heat exchangers, leading to higher cost of investment and complicated system. Therefore, further study is recommended to compare the two systems in term of economic analysis.

\section{Conclusions}

The SOFC system integrated with the bio-ethanol production and bio-ethanol purification was studied. The effects of operating parameters at $Q_{\text {net }}$ equal to zero on the SOFC performance were presented. The results showed that the system can be operated in an energy self-sufficient mode by adjusting the operating parameters. It was found that the most suitable operating voltage was between 0.7 and $0.85 \mathrm{~V}$ and the operating temperature was in the range from 973 to $1173 \mathrm{~K}$. Moreover the maximum overall efficiency and net electrical power were obtained when the percent ethanol recovery was equal to $95 \%$. The results also indicated that the integrated system of SOFC and bio-ethanol production and purification processes with heat integration was possible and offered high overall electrical efficiency. The biogas for hydrogen production to SOFC had the slightly higher efficiency than the biogas for cogeneration but more unit operations and equipment are required which leads to higher cost of investment and complicated system. Consequently, the further study is recommended that the economic evaluation should be done to compare among both systems 


\section{ACKNOWLEDGEMENT}

This work is supported by the Thailand Research Fund and Commission on Higher Education and MTEC. 


\section{REFERENCES}

[1] S. Yu and J. Tao, "Energy efficiency assessment by life cycle simulation of cassava-based fuel ethanol for automotive use in Chinese Guangxi context," Energy, vol. 34, no. 1, pp. 22-31, 2009.

[2] R. Leng, C. Wang, C. Zhang and D. Dai, "Life cycle inventory and energy analysis of cassava-based Fuel ethanol in China," Journal of Cleaner Production, vol. 16, no. 3, pp. 374-384, 2008.

[3] N. Chaisadtra, W. Nasomja and U. Hainghai, "A use of biogas produced from cassava's plant use water," (ME2004-58) Senior Project, Department of Mechanical Engineering, Faculty of Engineering, Khon Kaen University, Khon Kaen, 2005.

[4] W. Jamsak, et al., "Thermodynamic assessment of solid oxide fuel cell system integrated with bioethanol purification unit," Journal of Power Sources, vol. 174, no. 1, pp. 191-198, 2007.

[5] W. Jamsak, et al., "Design of a thermally integrated bioethanol-fuelled solid oxide fuel cell system integrated with a distillated column," Journal of Power Sources, vol. 187, no. 1, pp. 190-203, 2009.

[6] P. Piroonlerkgul, S. Assabumrungrat, N. Laosiripojana and A. A. Adesina, "Selection of appropriate fuel processor for biogas-fuelled SOFC system," Chemical Engineering Journal, vol. 140, no. 1-3, pp. 341-351, 2008.

[7] P. Piroonlerkgul, N. Laosiripojana, A. A. Adesina and S. Assabumrungrat, "Performance of biogas-fed solid oxide fuel cell systems integrated with membrane module for $\mathrm{CO}_{2}$ removal," Chemical Engineering and Processing: Process Intensification, vol. 48, no. 2, pp. 672-682, 2009. 